\title{
Public Debt, Sovereign Default Risk and Shadow Economy*
}

\author{
Ceyhun Elgin ${ }^{\dagger}$ \\ Burak R. Uras ${ }^{\ddagger}$ \\ Bogazici University \\ Tilburg University
}

\begin{abstract}
This paper analyzes the interactions between government's indebtedness, sovereign default risk and the size of the informal sector. We test an underlying theory that suggests that in societies with limited tax enforcement, the presence of informality constrains the set of pledgeable fiscal policy alternatives, increases public debt and the implied probability of sovereign debt restructuring. The hypotheses that we test in our empirical analysis are: a larger size of the informal sector is associated with (1) higher public indebtedness, (2) higher interest rates paid on sovereign debt, (3) a higher level of financial instability and (4) a higher probability of sovereign default. The empirical results from cross-country panel regressions show that after controlling for previously highlighted variables in the literature that could explain the variation in financial instability, sovereign default risk and public indebtedness, the size of informality remains as a significant determinant of these variables.
\end{abstract}

Keywords: Informal Sector; Public Debt; Sovereign Yields.

JEL Classification Numbers: F34, H26, H63.

${ }^{*}$ We are thankful to two anoonymous reviewers and the editor for helpful comments and suggestions. Moreoever, Ceyhun Elgin acknowledges support by the Bogazici University Research Fund (Project No: $6345)$.

${ }^{\dagger}$ Corresponding Author: Bogazici University, Department of Economics, Natuk Birkan Binasi Kat: 2 Bebek, 34342, Istanbul, Turkey. Phone: +90-212-359-7653. Fax: +90-212-287-2453. E-mail: ceyhun.elgin@boun.edu.tr.

‡Tilburg University, Department of Economics Room K322B 5000 LE Tilburg, The Netherlands. E-mail: r.b.uras@uvt.nl. 


\section{Introduction}

The data on sovereign debt yields exhibit substantial cross-country variation ${ }^{1}$. It is well understood that high interest rates paid on sovereign bonds are first-order constraining factors for economic well-being in developing countries. Therefore, a vast literature concentrated on understanding the determinants of sovereign debt defaults and the implied interest rates paid on sovereign debt ${ }^{2}$. Another important problem concerning the economic performance of the developing world is the limited enforcement of tax collection and the implied presence of a non-negligible size of the informal sector. ${ }^{3}$ Among other macroeconomic implications, the presence of a large shadow economy influences the choice of fiscal policy instruments, government tax revenues, and thus a government's ability to repay outstanding government $\mathrm{debt}^{4}$.

In this paper we address the interactions between these two seemingly related issues which has been previously overlooked in both strands of literature. Specifically, we address whether the size of the shadow economy provides any explanatory power in understanding the cross-country variation in public debt and indicators of sovereign default risk. To support our empirical study, we provide an underlying theoretical mechanism that associates the size of the informality with sovereign debt default risk. We suggest that in societies where the shadow economy accounts for a substantial amount of economic activity, the presence of informality, and tax evasion, limit the set of credible future fiscal policy adjustments and increases the probability of debt defaults and thereby affects the interest rates charged on sovereign debt. Our empirical results show that after controlling for previously highlighted variables in the literature that partially explain the variation in debt and interest rates paid on sovereign debt, the shadow economy size remains as a significant determinant for a

\footnotetext{
${ }^{1}$ Table 1 documents that interest rates paid on government has a mean around $8.4 \%$ and a standard deviation of $10.59 \%$.

${ }^{2}$ Eaton and Fernandez (1996) and Panizza et. al (2009) provide extensive surveys on the determinants of sovereign debt and default risk.

${ }^{3}$ Shadow economy or informal sector, sometimes also titled black, hidden or underground economy is defined by Hart (2008) as a set of economic activities that take place outside (as opposed to the formal sector) the framework of bureaucratic public and private sector establishments. Also, see Schneider and Enste, 2000 for comparison of various definitions.

${ }^{4}$ See Cicek and Elgin (2011).
} 
government's indebtedness and cost of sovereign debt.

The main issue concerning international lending is the problem of sustainable commitment at the two-sides of the international financial markets. Namely, commitment to repay at the borrower's side and commitment to enforce repayment at the lender's are necessary to keep interest rates low on sovereign debt. According to this view, traditional concepts of solvency and liquidity cannot explain problems of sovereign debt because creditors in international financial markets do not have the means to seize the assets of a defaulting borrower. In this respect, Eaton et. al (1986) suggest that the breakdown of either type of commitment may result in debt defaults, which can explain the sovereign debt repayment crises that occurred in LDC's during 1980s. In the current generation of sovereign debt crises, the limited commitment problem in financial markets is still accepted to be the major determinant of debt default/restructuring incidences observed in developing as well as in developed countries. Therefore, a good understanding of sovereign debt costs requires a careful analysis of the commitment issues in international financial markets. To this end, Panizza et. al (2009) find limited support for theories that explain the costs of sovereign debt based on either external sanctions or exclusion from the capital market (limited commitment at lender's side), and more support for explanations that emphasize domestic costs of default (limited commitment at borrower's side).

This paper contributes to the "domestic costs of default" perspective in explaining the variation in sovereign risk spreads. Our main hypothesis is that the presence and also the size of the shadow economy could potentially lower the cost of default and weaken borrower's commitment to collect taxes and repay debt ${ }^{5}$. A borrower's capacity to repay existing debt obligations is associated with pledgeable future contractions in fiscal policy. As long as a borrower can credibly commit to such future policy adjustments and promise future government surpluses he should be able to borrow in international financial markets at low costs and not face any sovereign debt feasibility problems. In our analysis, we claim that the size of the shadow economy constrains the set of pledgeable fiscal policy contractions. The

\footnotetext{
${ }^{5}$ Figure 1 provides a visual on the relationship between the probability of default and shadow economy size. As one can observe from the figure, the correlation between these two variables is strikingly positive.
} 
underlying mechanism associated with this theory is as follows: In an economy characterized with a large informal production, fiscal policy contractions associated with a tax rise can lead to an expansion in the size of the shadow economy and hence limit the amount of government surplus that can be generated resulting from a tax rise. Similarly, assuming that the size of the government purchases affects the quality of infrastructure in the formal economy and therefore the benefits from formal sector production, a contractionary fiscal policy associated with a decrease in government purchases could shrink the size of the formal sector production, lower the total amount of taxes collected, and again inhibit the government surplus produced from a decrease in government purchases. Due to the same line of reasoning, debt would emerge as an optimal source of government financing in the presence of shadow economy: A tax rise, or a decrease in government purchases would lead to a contraction in the size of the formal sector whereas a rise in government indebtedness would lead to an expansion in the size of the formal sector production. This limited fiscal pledgeability problem of domestic governments, and the demand for borrowing, in the presence of a shadow economy economy is expected to affect the probability of sovereign debt defaults/restructuring and increase sovereign debt interest rates and the level of financial stability

We empirically test the above mentioned hypotheses using panel and cross-country regressions. Specifically, we show that a larger shadow economy size is associated with

1. a higher amount of public debt,

2. relatively higher interest rates charged on sovereign debt,

3. a higher level of country financial instability and

4. a higher probability of sovereign default.

Moreover, we also list some policy recommendations, such as improving tax enforcement through enforcement of law and order and increasing the capital-output ratio, that can reduce the size of the shadow economy and mitigate sovereign debt default risk and financial instability. We also extend our empirical analysis to provide support for those policy prescriptions. 
The rest of the paper is organized as follows. Section 2 reviews the literature and among other things especially emphasizes the contribution of our paper. Section 3 provides the theoretical background for the interactions between the size of the informal sector, country's public indebtedness and sovereign interest rates (and sovereign default probability). Section 4 presents the empirical analysis. Section 5 addresses policy implications concerning the effects of informal sector size on public debt and sovereign default risk. Finally, section 6 concludes the paper.

\section{$2 \quad$ Related Literature}

The empirical literature on sovereign debt yields and the determinants of sovereign debt defaults is non-exhaustive. In this literature, many papers focused on the effects of country specific factors in explaining debt default incidences and the cross-country variation in debt yields. Edwards (1984) shows that the size of the external debt is key in determining the sovereign debt default probability whereas Reinhart et. al (2003) argue it is the country's history of default that determines the future likelihood of defaulting. Min (1998), Beck (2001), and Ferrucci (2003) suggest that macroeconomic variables such as domestic inflation rates, foreign asset positions, terms of trade and political risk are significant determinants of sovereign risk spreads. Some studies argue that global financial market conditions are important in determining credit risk spreads. In this respect, Calvo (2002), Grandes (2003), Gonzalez-Rozada and Levy Yeyati (2008) analyzed the effects of global factors for emerging market sovereign debt interest rates.

In this paper we study the quantitative effects of the informal sector size in determining cross-country variation in sovereign debt yields (interest rates charged on sovereign debt) and sovereign debt default probability. Similar to our perspective, there are other studies in the literature that concentrated on the fiscal determinants of sovereign debt yields. Faria (2006) shows that fiscal stability plays a significant role in determining sovereign bond spreads. Min (1998) finds when other macroeconomic variables are included, fiscal variables do not have any explanatory power for sovereign risk spreads. Close to the predictions that we derive in 
this paper, Hallerberg and Wolff (2008) show that fiscal policy is a significant determinant of debt yields in economies with weak institutions. To the best of our knowledge, our paper is the first study to analyze the size of the informal sector as a fiscal determinant of sovereign yields (interest rates) and sovereign default probability.

There is also a growing interest in macroeconomics in studying the interactions between the informal sector size and government policy. In particular, there are a number of studies that pointed a negative causal effect of taxes on the size of informal sector and long-run economic performance. Some important contributions in this respect are Rauch (1991), Loayza (1996), Ihrig and Moe (2004), and Amaral and Quintin (2006). Rauch (1991) shows that the interactions between minimum wage laws and taxation of formal sector entrepreneurs is responsible for a large informal sector size in developing countries. Similarly, Ihrig and Moe (2004) quantifies the importance of taxes and tax enforcement on the size of informal sector and macroeconomic development and concludes that the most efficient way of reducing informality is lowering the level of formal sector taxes. Our theoretical stand point in the paper, that shadow economy size and formal sector taxes are negatively related, aligns with the findings of this literature.

As we also argue in this paper, other studies suggested the importance of public expenditures in stimulating institutional development (such as lowering government corruption, increasing bureaucratic quality and improving the level of financial development) to increase the attractiveness of formal sector production. To this extent, we can list Friedman et. al (2000) and Elgin (2010) who studied the effects of bureaucratic quality on informal sector size; and Straub (2005), Antunes and Cavalcanti (2007) and Elgin and Uras (2011) who concentrated on the effects of financial development and entry barriers to formal sector production on shadow economy.

Our paper is the first attempt in studying the implications of informal sector size on the size of public indebtedness and sovereign debt yields. Therefore, we highlight a new macroeconomic channel through which informal sector might become important for the economic performance in developing world. In that sense our paper is unique in analyzing the 
relationship between these variables. Moreover, the uniqueness of our paper is also crucial when we consider how important the policy implications of the results are. Therefore, in this paper we also list (and empirically justify) some policy recommendations aiming to reduce sovereign default risk under the presence of an informal economy.

\section{Theoretical Background}

This section provides underlying theoretical interactions between the size of the informal sector, country's public indebtedness and sovereign risk premium and draw empirically testable hypotheses. We start the analysis with a benchmark assumption. Suppose an increase in the level of public indebtedness would leave a country's sovereign risk premium unchanged as long as the debt issuing government can credibly promise contractions in public spending or increases in the level of tax revenues in the future that could be exploited to repay the expansion in current government debt today. We argue that the ability to pledge using such long-run fiscal policy contractions is related to the current level of society's tax enforcement and the size of the informal sector. Specifically, if the tax enforcement in an economy is high, the government can promise an increase in the level of future taxes or a decrease in future government purchases to repay today's public debt. We assume that at the benchmark economy an increase in future taxes or a decrease in public spending implies an increase in government surplus under perfect tax enforcement.

In an economy where the tax enforcement is limited, a government's capacity to borrow against future increases in tax revenues is expected to be constrained. To understand the intuition behind this argument consider the following setting: Suppose, there are two sectors in the economy denoted as informal and formal. In the formal sector agents pay taxes and have access to a set of institutions. In the informal sector agents do not pay the full amount of formal taxes (to capture the friction associated with limited tax enforcement), but also have only a limited access to the institutions of the formal economy. In this type of a world agents choose the formal economy if the benefits from living in an environment with strong institutions outweighs the taxes paid to the government. Hence, in an economy 
with low tax enforcement an increase in the level of taxes (relative to an environment with high tax enforcement), not necessarily leads to an expansion in the level of tax revenues, even if taxation is non-distortionary, because the tax increase would stimulate a fraction of the agents to leave the formal economy and switch to the informal sector. As pointed out in Rauch (1991), Loayza (1996), Ihrig and Moe (2004), and Amaral and Quintin (2006), the larger the tax rise the higher the number of agents switching from the formal sector to the informal sector. Therefore, with imperfect tax enforcement an increase in government debt could potentially not be repaid with a future increase in taxes since in the presence of an informal sector increasing future taxes does not necessarily imply a rise in government surplus. We define this constrained set of alternative future fiscal policies in the presence of an informal sector as the "limited fiscal pledgeability" of a government.

A similar limited fiscal pledgeability problem arises if one looks at the issue from the perspective of public spending. Consider again the setting from the previous paragraph. But now, suppose that the size of the government purchases affects the quality of institutional environment and hence the benefits from the formal sector production. As Friedman et. al (2000) and Elgin (2010) argue, in this setting, a decrease in the level of government purchases would stimulate a reallocation of the agents from the formal sector to the informal sector which in turn reduces the size of the formal sector and lowers the total amount of taxes collected. Hence, in the presence of a large informal economy lowering the size of the public spending does not necessarily lead to an increase in government surplus either.

Due to the same line of reasoning, debt becomes an optimal source of financing for the government of an economy with a large informal sector. A tax rise, or a decrease in government purchases would lead to a contraction in the size of the formal sector whereas a rise in government indebtedness would lead to an expansion in the size of the formal sector production.

The government's limited fiscal pledgeability due to informal sector is expected to increase the probability of public debt defaults, or probability of debt restructuring and financial stress and influence the sovereign interest rates associated with government bonds. Therefore, we 
expect the strength of the tax enforcement and the implied size of the informal sector in an economy to affect a government's fiscal pledgeability, and hence, the size of the public debt, interest rates charged on debt, a country's financial stress and sovereign debt default probability. Therefore, the core hypotheses that we test in order of appearance in the empirical section are as follows. Ceteris paribus,

1. A large informal sector size (IS) is associated with high public indebtedness (PD), $(\partial P D / \partial I S>0)$

2. A large informal sector size is associated with high financial stress (FS), $(\partial F S / \partial I S>$ $0)$,

3. A large informal sector size is associated with high interest rates charged on government $\operatorname{debt}(\mathrm{R}),(\partial R / \partial I S>0)$,

4. A large informal sector size is associated with higher probability of sovereign default $(\mathrm{SD}),(\partial S D / \partial I S>0)$.

To test our hypothesis, in the next section, we provide cross-country regressions. We provide proxies for sovereign debt default probability, sovereign interest rates and size of the informal sector. Our analysis shows that after controlling for a set of country specific variables, such as inflation, institutional quality and political risk, the size of informal economy remains as a significant explanatory variable to explain the cross-country variation in sovereign debt, default probability and sovereign yields.

\section{Empirical Analysis}

\subsection{Methodology}

As outlined above, our main purpose in this empirical analysis is to study how public indebtedness and sovereign default risk are associated with the size of the shadow economy. We will use various variables to proxy country's default risk. In our sample the Sovereign 
Default Risk proxies are available in panel data (Financial Stress Index and Interest Rate) and also in cross-sectional data (the probability of sovereign default) formats. Public Debt is available as a panel. Therefore, when panel data is available (i.e. when the dependent variables are Financial Stress Index, Interest Rate and Public Debt), we will estimate the following reduced form equations

$$
\begin{aligned}
& \operatorname{Risk}_{i, t}=\beta_{0}+\beta_{1} I S_{i, t}+\sum_{k=3}^{2} \beta_{k} X_{k_{i, t}}+\theta_{i}+\epsilon_{i, t} \\
& \operatorname{Debt}_{i, t}=\beta_{0}+\beta_{1} I S_{i, t}+\sum_{k=3}^{2} \beta_{k} X_{k_{i, t}}+\theta_{i}+\epsilon_{i, t}
\end{aligned}
$$

In this econometric model, $R i s k_{i, t}$ stands for the measure we use to proxy the Sovereign Default Risk (Financial Stress Index and Interest Rate) for country $i$, in year $t, D_{e b t} t_{i, t}$ is country $i$ 's outstanding government debt in year $i$, and $I S_{i, t}$ is the size of the informal sector, or in other words the shadow economy size. $X_{k_{i, t}}$ are control variables that have been highlighted in the empirical literature that could potentially explain the variation in sovereign default risk and country's public indebtedness. $\theta_{i}$ is a country fixed effect. Finally, $\epsilon_{i, t}$ denotes the error term. We estimate this equation using a fixed-effects estimator.

In the case of cross-country regression analysis (i.e. when the left hand side variable is the historical probability of sovereign debt default), we estimate the following linear equation using the standard OLS estimator

$$
\operatorname{Risk}_{i}=\beta_{0}+\beta_{1} I S_{i}+\sum_{k=3}^{2} \beta_{k} X_{k_{i}}+\epsilon_{i} .
$$

In this latter model specification, $R i s k_{i}$ is again the measure we use to proxy risk of default for country $i$ (probability of sovereign debt default), and $I S_{i}$ is the shadow economy size. $X_{k_{i}}$ are other explanatory variables in addition to shadow economy and finally $\epsilon_{i}$ is the error term.

Moreover, in each case, suspecting the presence of endogeneity which may stem from the existence of reverse causality, simultaneity, omitted variable bias or measurement errors 
we also run an instrumental variable (IV) regressions ${ }^{6}$ where we instrument the size of the informal sector by certain determinants of informality, namely the law and order index, and the capital-output ratio. $^{7}$

Table 1: Summary Statistics for the Panel: 1999-2007.

\begin{tabular}{llllll}
\hline \hline Variable & Mean & Std. Deviation & Minimum & Maximum & Observations \\
\hline \hline Public Debt (\% GDP) & 54.11 & 31.95 & 0.21 & 247.38 & 448 \\
Interest Rate (\%) & 8.04 & 10.59 & 0.01 & 20.34 & 1209 \\
FSI & -0.73 & 1.57 & -4.59 & 3.89 & 306 \\
Default Probability (\%) & 19.63 & 18.09 & 0.00 & 64.00 & 65 \\
\hline Informal Sector Size (\% GDP) & 33.14 & 12.98 & 8.10 & 68.30 & 1365 \\
GDP per-capita (thousand \$) & 7.11 & 10.36 & 0.08 & 56.62 & 1355 \\
Trade Openness (\% GDP) & 89.55 & 52.53 & 4.83 & 453.44 & 1359 \\
Current Account Deficit (\% GDP) & -3.06 & 59.96 & -253.00 & 364.47 & 1326 \\
Corruption Control & 2.78 & 1.22 & 0.00 & 6.00 & 1176 \\
Bureaucratic Quality Index & 2.23 & 1.11 & 0.00 & 4.00 & 1179 \\
Democratic Accountability & 4.00 & 1.68 & 0.00 & 6.00 & 1174 \\
Political Stability & 9.24 & 1.35 & 4.46 & 12.00 & 1172 \\
Inflation (\%) & 2.06 & 11.48 & -9.82 & 103.431 & 1367 \\
Growth (\%) & 3.49 & 622 & -13.85 & 12.37 & 1359 \\
Law and Order & 3.89 & 1.35 & 0.50 & 6.00 & 1177 \\
Capital-Output Ratio & 2.33 & 1.57 & 0.42 & 10.91 & 1368 \\
Income Tax Burden (\% GDP) & 17.16 & 7.07 & 0.82 & 57.49 & 1140 \\
Unemployment (\%) & 8.88 & 5.85 & 2.70 & 37.30 & 816 \\
\hline \hline
\end{tabular}

\subsection{Data}

We run four sets of regressions with four different dependent variables. In our panel regressions we use the ratio of public debt to GDP, interest rate spread, and financial stress index (FSI) as the dependent variables and in the cross-sectional OLS probability of default is our dependent variable. Public debt and interest rate series are obtained from the World Development Indicators (WDI) of the World Bank. In the latter case, reported results use

\footnotetext{
${ }^{6}$ To check for reverse causality or the possible existence of a feedback effect between informality and for example public debt, we also have run several system estimations, which we omit, in the current draft for space constraints. However, these results are available from the corresponding author upon request

${ }^{7} \mathrm{We}$ will also use the law and order index later in system estimations along with tax burden and unemployment as factors that are highly correlated with informal sector size. Here, tax burden and unemployment are not used instruments as they potentially are not exogenous to public debt.
} 
interest rate spread defined as the difference between lending rate and the deposit rate. ${ }^{8}$ Moreover, FSI is obtained from the IMF and finally the probability of default is constructed using the data reported by Reinhart and Rogoff (2009). In addition to the public debt to GDP ratio and the interest rate, we believe that the FSI index is also a good measure of sovereign default risk as it measures the degree of financial stress in a given country. The FSI for each country is constructed as an average of the following indicators ${ }^{10}$ : Three bankingrelated variables, namely the beta of banking sector stocks; the spread between interbank rates and the yield on treasury bills; and the slope of the yield curve; three securities-marketrelated variables, corporate bond spreads, stock market returns, and time-varying stock return volatility; and finally one foreign exchange variable, time-varying effective exchange rate volatility. ${ }^{11}$ Finally, in the last case, the default probability for each country is calculated as the number of sovereign default episodes that occurred between 1960 and 2008 divided by the number of years since 1960 (or year of independence). Notice that, as opposed to the other variables which are available as a panel, this series is available only as only cross-section data. Also we should yield that the number of observations is very different for each of the four default risk measure. These differences stem from variations in data availability given by our data sources.

To estimate the size of the informal sector (shadow economy), we use panel estimates from Schneider et. al (2010) for the time interval from 1999 through 2007 which uses a MIMIC (multiple-indicator multiple-cause) approach. According to this paper, the informal sector ${ }^{1}$ are market-oriented production activities that are hidden from state authority to avoid, payment of income, value added, or other taxes, payment of social security contributions, having to meet certain legal labor market standards, such as minimum wages, maximum

\footnotetext{
${ }^{8}$ For robustness checks, we also used several other interest rate measures such as the average interest on new external public debt commitments (from WDI) and average interest on existing public debt (constructed from GFS of IMF) real interest rate and risk premium on lending (both from WDI), i.e. prime rate minus treasury bill rate. Not surprisingly, all these variables (including the interest rate spread used in the regressions) are highly correlated (correlations above 0.80 ) with each other ${ }^{9}$. Therefore, in the regressions we report the one with highest number of observations that is the interest rate spread and refer a more interested reader to the corresponding author for additional regressions results using other measures of interest rates.

${ }^{10}$ Illing and Liu (2006) uses a similar approach to measure FSI for Canada and show that debt defaults are one of the pivotal stress events.

${ }^{11}$ See further Cardarelli et al. (2009) and Balakrishnan et al. (2009) for definitions.
} 
working hours, safety standards; and complying with certain administrative procedures, such as completing statistical questionnaires or other administrative forms. ${ }^{12}$ Our informal sector data covers 152 countries over a time span of 9 years.

We control for a number of variables that have been highlighted in the literature as potential determinants of sovereign risk spreads. In this respect, the control variables GDP per-capita, trade openness and current account balance are from the Penn World Tables 7.0. As a measure of corruption control, we use the corruption control index from the International Country Risk Guide (ICRG) provided by the Political Risk Services (PRS). Similarly, the indices of bureaucratic quality, political stability and democratic accountability are obtained from ICRG, as well. These four variables aim to control for institutional quality. The greater values of these indices imply better institutional development. Finally, the inflation data is

obtained from the World Development Indicators of the World Bank. ${ }^{13}$ Descriptive statics for all variables used in this section can be found in Table 1.

Table 2: Regional Averages

\begin{tabular}{llll}
\hline \hline Region & Informal Sector (\% GDP) & Public Debt (\% GDP) & Int. Rate Spread \% \\
\hline \hline OECD-EU & 16.01 & 33.18 & 4.08 \\
Latin & 36.14 & 54.34 & 12.30 \\
Asia & 25.10 & 33.72 & 9.09 \\
Other & 39.42 & 57.72 & 14.09 \\
\hline World & 33.14 & 54.11 & 8.04 \\
Developed & 15.62 & 32.18 & 4.08 \\
Emerging Markets & 38.22 & 49.99 & 11.92 \\
\hline \hline
\end{tabular}

Moreover, in Table 2, we compare averages of three key variables of our dataset, namely informal sector size and public debt as \% of GDP and interest rate spread in several subsets of our data. We will make an empirical analysis in more detail in the following subsections of

\footnotetext{
${ }^{12}$ See Schneider and Enste (2000), Schenider (2002, 2005) and Schneider et. al (2010) for details of this methodology.

${ }^{13}$ For further robustness checks, we have also added the ratio of government spending to GDP, income tax burden, the ratio of government fiscal balance to GDP and an indicator variable representing whether there is a default in the history of the country or not, to the regressions as independent variables; but our results did not change qualitatively. These further regression outputs are available upon request from the corresponding author.
} 
this section; however a visual inspection of Table 2 reveals two key facts: Looking at regional averages, informal sector size has a positive correlation with both public debt and interest rate spread. Surely, further econometric analysis is needed to establish a robust correlation between these variables. This is what we do in the next subsection.

Table 3: Public Debt and Informal Sector

Dep. Var.: Debt

\begin{tabular}{|c|c|c|c|c|c|c|c|c|c|}
\hline & $(1)$ & $(2)$ & $(3)$ & (4) & $(5)$ & (6) & $(7)$ & $(8)$ & (9) \\
\hline \multirow[t]{2}{*}{$\overline{\mathrm{IS}}$} & $4.75^{*}$ & $4.29^{*}$ & $4.23^{*}$ & $4.21^{*}$ & $3.34^{*}$ & $3.83^{*}$ & 3.78* & $3.79^{*}$ & $3.11^{*}$ \\
\hline & $(0.91)$ & $(0.98)$ & $(0.94)$ & $(0.93)$ & $(0.83)$ & $(0.71)$ & $(0.70)$ & $(0.73)$ & $(0.51)$ \\
\hline \multirow[t]{2}{*}{ GDP per-capita } & & -0.82 & -0.96 & 1.16 & $-1.35^{* * *}$ & $-1.43^{* *}$ & $-1.71^{* *}$ & $-1.72^{* *}$ & $-1.10^{* *}$ \\
\hline & & $(0.55)$ & $(0.64)$ & $(0.73)$ & $(0.71)$ & $(0.68)$ & $(0.69)$ & $(0.69)$ & $(0.53)$ \\
\hline \multirow[t]{2}{*}{ Openness } & & & 0.03 & 0.02 & 0.03 & 0.05 & 0.05 & 0.05 & 0.04 \\
\hline & & & $(0.05)$ & $(0.10)$ & $(0.09)$ & $(0.08)$ & $(0.08)$ & $(0.09)$ & $(0.07)$ \\
\hline \multirow[t]{2}{*}{ Current Account } & & & & -0.01 & 0.03 & 0.05 & 0.05 & 0.06 & 0.08 \\
\hline & & & & $(0.09)$ & $(0.09)$ & $(0.08)$ & $(0.09)$ & $(0.08)$ & $(0.12)$ \\
\hline \multirow[t]{2}{*}{ Bureaucratic Qual. } & & & & & 3.14 & 3.28 & 4.63 & 4.64 & 3.90 \\
\hline & & & & & $(8.39)$ & $(7.87)$ & $(8.21)$ & $(8.20)$ & $(7.10)$ \\
\hline \multirow[t]{2}{*}{ Corruption Control } & & & & & & $-2.41^{* *}$ & -1.76 & $-1.76^{* * *}$ & $-1.10^{* *}$ \\
\hline & & & & & & $(1.05)$ & $(1.09)$ & $(1.08)$ & $(0.50)$ \\
\hline \multirow[t]{2}{*}{ Democratic Acc. } & & & & & & & -1.94 & -1.93 & -.0 .80 \\
\hline & & & & & & & $(2.63)$ & $(2.65)$ & $(1.90)$ \\
\hline \multirow[t]{2}{*}{ Political Stability } & & & & & & & -0.77 & -0.77 & -0.55 \\
\hline & & & & & & & $(0.68)$ & $(0.68)$ & $(0.67)$ \\
\hline \multirow[t]{2}{*}{ Inflation } & & & & & & & & 0.003 & 0.02 \\
\hline & & & & & & & & $(0.05)$ & $(0.09)$ \\
\hline \multirow[t]{2}{*}{ Growth } & & & & & & & & 0.02 & 0.11 \\
\hline & & & & & & & & $(0.19)$ & $(0.20)$ \\
\hline$R$-squared & 0.20 & 0.21 & 0.22 & 0.23 & 0.21 & 0.22 & 0.23 & 0.23 & 0.19 \\
\hline Observations & 448 & 448 & 448 & 435 & 401 & 400 & 396 & 396 & 396 \\
\hline F-Test & 27.44 & 14.62 & 10.43 & 8.26 & 5.76 & 8.09 & 6.78 & 6.00 & 6.70 \\
\hline Hansen Test & & & & & & & & & 0.24 \\
\hline
\end{tabular}

All panel regressions include a country fixed effect. Robust standard errors are reported in parentheses. *, **, ${ }^{* * *}$ denote 1,5 and $10 \%$ confidence levels, respectively. In all regressions a constant is also included but not reported.

\subsection{Results}

Panel data estimation results are reported in tables between 3 through 6 . Table 3 summarizes results from linear regressions where we use the ratio of public debt to GDP as the 
dependent variable. Similar to the next two tables, here we run 9 regressions by adding different independent variables in each step. Different than the first 8 regressions, in regression 9 we report the instrumental variable fixed-effect regression results where we instrument informal sector size by several variables. ${ }^{14}$ In the case of IV estimation we also report the Hansen test statistic for over-identifying restrictions in which the null hypotheses of valid instruments are not rejected in any of the reported results. What we observe from Table 4 is that the size of the informal sector (IS) has significant explanatory power for the variation in country's public indebtedness (significant at $1 \%$ in all regressions). The other two variables that have significant regression coefficients are GDP per-capita and corruption control indices. The coefficient signs associated with these two variables are negative as expected.

In Table 4, we report estimation results when we use the Financial Stress Index (FSI) as the dependent variable of the regression. Again, as evident from row 1, the size of the shadow economy is positively correlated with FSI. Other variables that are correlated with FSI are corruption control, political stability and inflation. Coefficients of political stability and inflation are as expected positive and negative, respectively. On the other hand, somewhat surprisingly, high levels of corruption control are associated with high levels of FSI. Taking into account the fact that corruption sometimes provides room for investors to overcome the bureaucratic inefficiencies and barriers, especially in certain developing economies, might be the underlying factor behind this result.

In Table 5, we provide estimation results from regressions where we use the interest rate spread as the dependent variable. As for the coefficient of the shadow economy size, the results are quite similar to the previous sets of regressions. In addition to the shadow economy size, inflation, political stability, openness and current account balance are also significant in explaining the variation in the interest rates. Results for inflation and political stability are similar to the case of FSI, political stability decreases interest rates whereas inflation increases them. On the other hand, openness and a current account deficit are

\footnotetext{
${ }^{14}$ In the reported regressions results in this subsection we use law and order index, capital-output ratio and income tax burden as instruments. However, we also tested various other specifications with different combination of instruments and obtained similar results in these cases.
} 
Table 4: Financial Stress and Informal Sector

Dep. Var.: FSI

\begin{tabular}{|c|c|c|c|c|c|c|c|c|c|}
\hline & (1) & (2) & (3) & (4) & (5) & (6) & (7) & (8) & (9) \\
\hline$\overline{\mathrm{IS}}$ & $\begin{array}{l}0.89^{*} \\
(0.08)\end{array}$ & $\begin{array}{l}0.90^{*} \\
(0.08)\end{array}$ & $\begin{array}{l}0.90^{*} \\
(0.09)\end{array}$ & $\begin{array}{l}0.91^{*} \\
(0.09)\end{array}$ & $\begin{array}{l}0.91^{*} \\
(0.09)\end{array}$ & $\begin{array}{l}0.87^{*} \\
(0.08)\end{array}$ & $\begin{array}{l}0.85^{*} \\
(0.08)\end{array}$ & $\begin{array}{l}0.82^{*} \\
(0.08)\end{array}$ & $\begin{array}{l}0.93^{*} \\
(0.19)\end{array}$ \\
\hline GDP per-capita & & $\begin{array}{l}0.01 \\
(0.08)\end{array}$ & $\begin{array}{l}0.003 \\
(0.08)\end{array}$ & $\begin{array}{l}0.03 \\
(0.09)\end{array}$ & $\begin{array}{l}0.03 \\
(0.09)\end{array}$ & $\begin{array}{l}0.08 \\
(0.08)\end{array}$ & $\begin{array}{l}0.12 \\
(0.09)\end{array}$ & $\begin{array}{l}0.14 \\
(0.09)\end{array}$ & $\begin{array}{l}0.02^{* * * *} \\
(0.01)\end{array}$ \\
\hline Openness & & & $\begin{array}{l}0.001 \\
(0.006)\end{array}$ & $\begin{array}{c}-0.009 \\
(0.01)\end{array}$ & $\begin{array}{c}-0.006 \\
(0.01)\end{array}$ & $\begin{array}{c}-0.004 \\
(0.01)\end{array}$ & $\begin{array}{l}0.002 \\
(0.01)\end{array}$ & $\begin{array}{l}0.0005 \\
(0.01)\end{array}$ & $\begin{array}{l}0.01 \\
(0.01)\end{array}$ \\
\hline Current Account & & & & $\begin{array}{l}-0.01 \\
(0.01)\end{array}$ & $\begin{array}{l}-0.01 \\
(0.01)\end{array}$ & $\begin{array}{l}-0.02^{* * *} \\
(0.01)\end{array}$ & $\begin{array}{l}-0.01 \\
(0.01)\end{array}$ & $\begin{array}{l}-0.01 \\
(0.01)\end{array}$ & $\begin{array}{l}-0.02 \\
(0.02)\end{array}$ \\
\hline Bureaucratic Qual. & & & & & $\begin{array}{l}0.66 \\
(0.57)\end{array}$ & $\begin{array}{l}0.68 \\
(0.55)\end{array}$ & $\begin{array}{l}0.58 \\
(0.55)\end{array}$ & $\begin{array}{l}0.55 \\
(0.54)\end{array}$ & $\begin{array}{l}0.40 \\
(0.54)\end{array}$ \\
\hline Corruption Control & & & & & & $\begin{array}{l}0.73^{*} \\
(0.15)\end{array}$ & $\begin{array}{l}0.60^{*} \\
(0.16)\end{array}$ & $\begin{array}{l}0.53^{*} \\
(0.16)\end{array}$ & $\begin{array}{l}0.40^{* *} \\
(0.21)\end{array}$ \\
\hline Democratic Acc. & & & & & & & $\begin{array}{l}0.24 \\
(0.15)\end{array}$ & $\begin{array}{l}0.21 \\
(0.15)\end{array}$ & $\begin{array}{l}0.17 \\
(0.29)\end{array}$ \\
\hline Political Stability & & & & & & & $\begin{array}{l}-0.15^{* *} \\
(0.08)\end{array}$ & $\begin{array}{l}-0.15^{* *} \\
(0.08)\end{array}$ & $\begin{array}{l}-0.10^{* * *} \\
(0.06)\end{array}$ \\
\hline Inflation & & & & & & & & $\begin{array}{l}0.01^{* *} \\
(0.006)\end{array}$ & $\begin{array}{l}0.01^{* * *} \\
(0.006)\end{array}$ \\
\hline Growth & & & & & & & & $\begin{array}{c}-0.01^{* *} \\
(0.006)\end{array}$ & $\begin{array}{l}-0.01 * * * \\
(0.006)\end{array}$ \\
\hline$R$-squared & 0.34 & 0.34 & 0.34 & 0.34 & 0.34 & 0.39 & 0.41 & 0.42 & 0.37 \\
\hline Observations & 306 & 306 & 306 & 305 & 305 & 305 & 305 & 305 & 305 \\
\hline F-Test & 137.57 & 68.53 & 45.53 & 33.96 & 27.46 & 28.74 & 22.72 & 20.92 & 17.10 \\
\hline Hansen Test & & & & & & & & & 0.31 \\
\hline
\end{tabular}

All panel regressions include a country fixed effect. Robust standard errors are reported in parentheses. *, **, ${ }^{* * *}$ denote 1,5 and $10 \%$ confidence levels, respectively. In all regressions a constant is also included but not reported.

also associated with higher interest rates. However, the coefficient of openness loses its significance in the IV estimation case.

The final set of regressions in this section report cross-sectional estimates when we use the probability of default as the dependent variable. ${ }^{15}$ In this respect, Figure 1 provides a clear visual on the relationship between the probability of default and shadow economy size. As one can observe from the figure, the correlation between these two variables is strikingly positive.

\footnotetext{
${ }^{15}$ Here we use averages over the period $1999-2007$ for all the right-hand-side variables.
} 
Table 5: Interest Rate and Informal Sector

Dep. Var.: Int. Rate

\begin{tabular}{llllllllll} 
& $(1)$ & $(2)$ & $(3)$ & $(4)$ & $(5)$ & $(6)$ & $(7)$ & $(8)$ & $(9)$ \\
\hline \hline IS & $1.49^{*}$ & $1.41^{*}$ & $1.49^{*}$ & $1.55^{*}$ & $1.76^{*}$ & $1.62^{*}$ & $1.57^{*}$ & $1.50^{*}$ & $1.12^{*}$ \\
& $(0.17)$ & $(0.14)$ & $(0.14)$ & $(0.15)$ & $(0.16)$ & $(0.17)$ & $(0.17)$ & $(0.17)$ & $(0.21)$ \\
GDP per-capita & & -0.12 & -0.26 & -0.27 & -0.27 & -0.27 & -0.21 & -0.18 & $-0.22^{* * *}$ \\
& & $(0.22)$ & $(0.22)$ & $(0.23)$ & $(0.25)$ & $(0.25)$ & $(0.25)$ & $(0.25)$ & $(0.12)$ \\
Openness & & & $0.05^{*}$ & $0.06^{*}$ & $0.08^{*}$ & $0.09^{*}$ & $0.09^{*}$ & $0.09^{*}$ & 0.07 \\
& & & $(0.01)$ & $(0.02)$ & $(0.02)$ & $(0.02)$ & $(0.02)$ & $(0.02)$ & $(0.07)$ \\
Current Account & & & & $0.02^{* *}$ & $0.03^{* *}$ & $0.03^{* *}$ & $0.03^{* *}$ & $0.03^{* *}$ & $0.04^{* *}$ \\
& & & & $(0.01)$ & $(0.01)$ & $(0.01)$ & $(0.01)$ & $(0.01)$ & $(0.02)$ \\
Bureaucratic Qual. & & & & & 1.74 & 1.60 & 1.60 & 1.55 & 2.10 \\
& & & & & $(1.09)$ & $(1.08)$ & $(1.11)$ & $(1.10)$ & $(1.90)$ \\
Corruption Control & & & & & & $0.88^{* *}$ & 0.60 & 0.50 & 0.15 \\
& & & & & & $(0.35)$ & $(0.37)$ & $(0.37)$ & $(0.29)$ \\
Democratic Acc. & & & & & & & 0.55 & 0.52 & 0.70 \\
& & & & & & & $-0.45)$ & $(0.45)$ & $(0.50)$ \\
Political Stability & & & & & & & $(0.19)$ & $(0.19)$ & $(0.20)$ \\
& & & & & & & & $0.05^{*}$ & $0.05^{* *}$ \\
Inflation & & & & & & & & $(0.02)$ & $(0.02)$ \\
& & & & & & & & $-0.02^{* *}$ & $-0.03^{* *}$ \\
Growth & & & & & & & & $(0.01)$ & $(0.01)$ \\
& 0.07 & 0.22 & 0.12 & 0.12 & 0.14 & 0.14 & 0.15 & 0.16 & 0.20 \\
\hline \hline$R$-squared & 1206 & 1195 & 1195 & 1169 & 994 & 991 & 986 & 985 & 985 \\
Observations & 79.68 & 65.78 & 48.87 & 36.43 & 28.52 & 24.21 & 19.18 & 18.13 & 20.10 \\
F-Test & & & & & & & & & 0.18 \\
Hansen Test & & & & & & & & & \\
\hline
\end{tabular}

All panel regressions include a country fixed effect. Robust standard errors are reported in parentheses. *, **, ${ }^{* * *}$ denote 1,5 and $10 \%$ confidence levels, respectively. In all regressions a constant is also included but not reported.

Notice that the sample size is quite small in this case as only a limited number of data observations are available for default probability. ${ }^{16}$ What we observe from Table 6 is that, in addition to GDP per-capita, bureaucratic quality, current account deficit, corruption control and inflation; the size of the informal sector is significantly related to the probability of default.

Our theory suggested that in societies where the informal sector production accounts for a substantial amount of economic activity, the presence of informality limits the set of

\footnotetext{
${ }^{16}$ Reduced sample size also necessitates to drop some independent variables we used in panel regressions as including them create collinearity issues.
} 


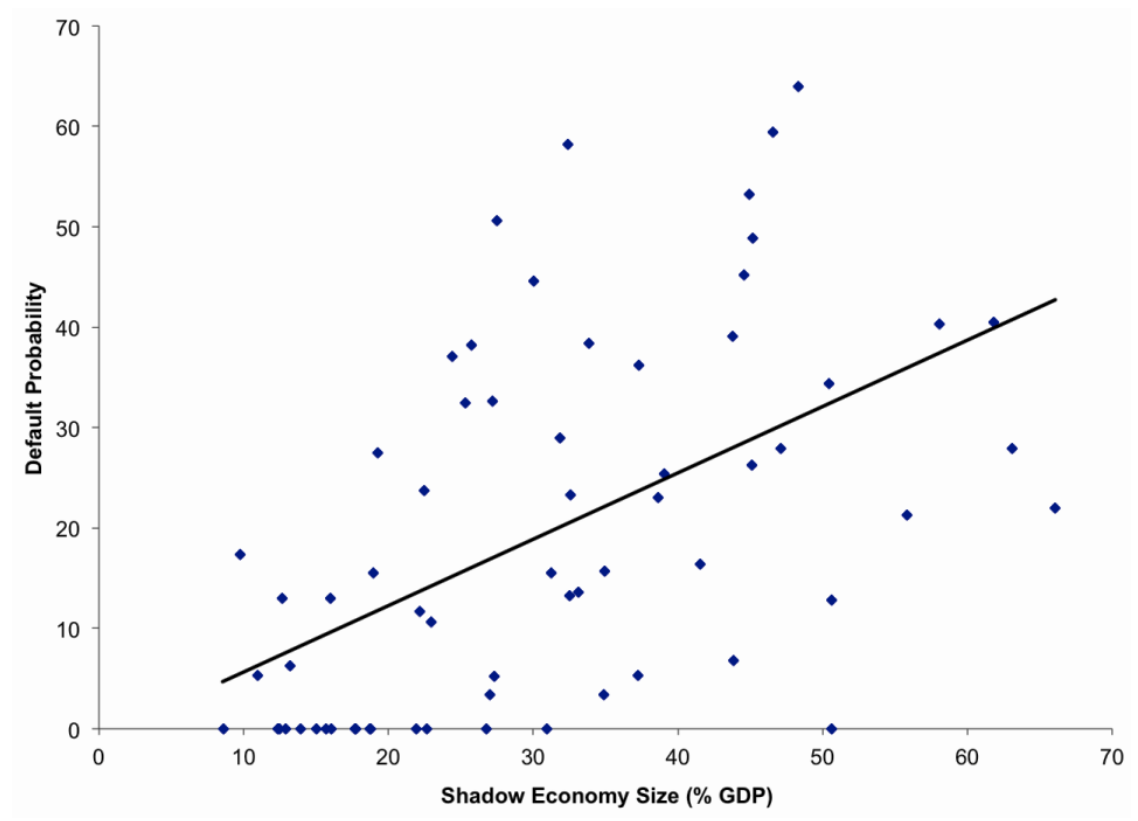

Figure 1: Probability of Default and Shadow Economy Size

credible future fiscal policy adjustments and increases the probability of debt defaults and thereby affects the interest rates paid on sovereign debt. The empirical results presented in this section show that after controlling for a number explanatory variables that could explain the variation in debt and interest rates paid on sovereign debt, the shadow economy size remains as a significant determinant of a government's indebtedness, cost of sovereign debt and a country's financial stress.

\subsection{Robustness Checks}

In this subsection we present several robustness checks of the empirical results we provided in the previous subsection.

We conduct three different checks. In the first one, considering that the default risk dynamics of developed and developing economies (or emerging markets) might be different we divide our dataset into two subsets: Developed and developing economies. When making this division and creating the dataset for emerging markets, we simply exclude ${ }^{17}$ countries under the very high human developed index category. (See UNDP, 2010) we divided Schneider,

\footnotetext{
${ }^{17}$ We could have made another stratification based on the GDP per capita values of the countries. However, notice that in the regression analysis as we have already controlled for GDP per capita. So our estimation results are already robust to the variation of GDP per capita.
} 
Dep. Var.: Default Prob.

\begin{tabular}{|c|c|c|c|c|c|c|c|c|}
\hline & (1) & (2) & (3) & (4) & (5) & (6) & $(7)$ & (8) \\
\hline$\overline{\mathrm{IS}}$ & $\begin{array}{l}0.66^{*} \\
(0.04)\end{array}$ & $\begin{array}{l}0.33^{*} \\
(0.05)\end{array}$ & $\begin{array}{l}0.32^{*} \\
(0.05)\end{array}$ & $\begin{array}{l}0.28^{*} \\
(0.05)\end{array}$ & $\begin{array}{l}0.16^{*} \\
(0.05)\end{array}$ & $\begin{array}{l}0.18^{*} \\
(0.05)\end{array}$ & $\begin{array}{l}0.20^{*} \\
(0.05)\end{array}$ & $\begin{array}{l}0.77^{*} \\
(0.13)\end{array}$ \\
\hline GDP per-capita & & $\begin{array}{l}-0.61^{*} \\
(0.05)\end{array}$ & $\begin{array}{l}-0.60^{*} \\
(0.05)\end{array}$ & $\begin{array}{l}-0.62^{*} \\
(0.06)\end{array}$ & $\begin{array}{l}-0.49^{*} \\
(0.07)\end{array}$ & $\begin{array}{l}-0.56^{*} \\
(0.08)\end{array}$ & $\begin{array}{l}-0.51^{*} \\
(0.08)\end{array}$ & $\begin{array}{l}-0.44^{*} \\
(0.06)\end{array}$ \\
\hline Openness & & & $\begin{array}{l}-0.02^{* * *} \\
(0.01)\end{array}$ & $\begin{array}{l}0.01 \\
(0.01)\end{array}$ & $\begin{array}{l}0.03^{* *} \\
(0.01)\end{array}$ & $\begin{array}{l}0.02^{* * * *} \\
(0.02)\end{array}$ & $\begin{array}{l}0.01 \\
(0.01)\end{array}$ & $\begin{array}{l}0.02 \\
(0.02)\end{array}$ \\
\hline Current Account & & & & $\begin{array}{l}0.07^{*} \\
(0.01)\end{array}$ & $\begin{array}{l}0.07^{*} \\
(0.01)\end{array}$ & $\begin{array}{l}0.07^{*} \\
(0.01)\end{array}$ & $\begin{array}{l}0.07^{*} \\
(0.01)\end{array}$ & $\begin{array}{l}0.05^{* *} \\
(0.02)\end{array}$ \\
\hline Bureaucratic Qual. & & & & & $\begin{array}{l}-3.28^{*} \\
(0.90)\end{array}$ & $\begin{array}{l}-3.95^{*} \\
(0.97)\end{array}$ & $\begin{array}{l}-4.56^{*} \\
(0.96)\end{array}$ & $\begin{array}{l}-4.17^{*} \\
(0.90)\end{array}$ \\
\hline Corruption Control & & & & & & $\begin{array}{l}1.60^{* *} \\
(0.66)\end{array}$ & $\begin{array}{l}2.43^{*} \\
(0.67)\end{array}$ & $\begin{array}{l}1.70^{* * *} \\
(0.90)\end{array}$ \\
\hline Inflation & & & & & & & $\begin{array}{l}0.99^{*} \\
(0.14)\end{array}$ & $\begin{array}{l}0.70^{* *} \\
(0.35)\end{array}$ \\
\hline Growth & & & & & & & $\begin{array}{l}0.30 \\
(0.35)\end{array}$ & $\begin{array}{l}0.27 \\
(0.35)\end{array}$ \\
\hline$R$-squared & 0.28 & 0.35 & 0.36 & 0.40 & 0.41 & 0.41 & 0.45 & 0.48 \\
\hline Observations & 65 & 65 & 65 & 65 & 65 & 65 & 65 & 65 \\
\hline $\begin{array}{l}\text { F-Test } \\
\text { Hansen Test }\end{array}$ & 267.61 & 281.27 & 206.35 & 164.39 & 128.86 & 101.67 & 107.49 & $\begin{array}{l}100.10 \\
0.15\end{array}$ \\
\hline
\end{tabular}

Robust standard errors are reported in parentheses. *,**, *** denote 1,5 and $10 \%$ confidence levels, respectively. In all regressions a constant is also included but not reported.

Buehn and Montenegro's dataset into two subsets: Developed and developing economies. This division creates a subset of 114 emerging markets and another one of 38 developed economies.

Table 7 reports estimation results using these two subsets of our data. As the FSI data is overwhelmingly on developed economies and the probability of default data only consists of 65 countries, we only run regressions with public debt and interest rate spread as dependent variables. In total we run 8 regressions, 4 using OLS and another 4 using the IV estimator. In every case we run one OLS and one IV regression for the subset of developed economies (DC) and another one emerging markets. (EM) As we can observe from Table 6, in every regression the coefficient of the informal sector size is positive and significant.

In the next robustness check, considering several critics of the dataset constructed by 
Table 7: Robustness Checks: Developed vs. Developing

\begin{tabular}{|c|c|c|c|c|c|c|c|c|}
\hline Dep. Var. & Debt & Debt & Debt & Debt & Int. & Int. & Int. & Int. \\
\hline & $\mathrm{DC}$ & EM & $\mathrm{DC}$ & EM & $\mathrm{DC}$ & EM & $\mathrm{DC}$ & EM \\
\hline & (OLS) & (OLS) & (IV) & (IV) & (OLS) & (OLS) & (IV) & (IV) \\
\hline$\overline{I S}$ & $3.10^{*}$ & $4.23^{*}$ & $2.32^{*}$ & $3.28^{*}$ & $1.16^{*}$ & $2.18^{*}$ & $1.02^{*}$ & $1.57^{* *}$ \\
\hline CDP ner_canita & $\begin{array}{l}(0.74) \\
-123 * *\end{array}$ & $\begin{array}{l}(0.75) \\
-0.91 *\end{array}$ & $\begin{array}{l}(0.55) \\
-110 *\end{array}$ & $\begin{array}{l}(0.79) \\
-160 *\end{array}$ & $\begin{array}{l}(0.15) \\
0.09 * * *\end{array}$ & $\begin{array}{l}(0.20) \\
-0.56 * *\end{array}$ & $(0.14)$ & $\begin{array}{l}(0.23) \\
0.44 * * *\end{array}$ \\
\hline & $(0.60)$ & $(0.30)$ & $(0.25)$ & $(0.26)$ & $(0.05)$ & $(0.28)$ & $(0.18)$ & $(0.23)$ \\
\hline Openness & $\begin{array}{l}0.03 \\
(0.02)\end{array}$ & $\begin{array}{l}0.02 \\
(0.10)\end{array}$ & $\begin{array}{l}-0.02 \\
(0.01)\end{array}$ & $\begin{array}{l}0.02^{* * * *} \\
(0.01)\end{array}$ & $\begin{array}{l}0.08 \\
(0.07)\end{array}$ & $\begin{array}{l}0.12 * * \\
(0.05)\end{array}$ & $\begin{array}{l}0.03 \\
(0.02)\end{array}$ & $\begin{array}{l}0.07 \\
(0.07)\end{array}$ \\
\hline Current Account & $\begin{array}{l}0.05 \\
(0.10)\end{array}$ & $\begin{array}{l}0.08 \\
(0.19)\end{array}$ & $\begin{array}{l}0.08 \\
(0.09)\end{array}$ & $\begin{array}{l}0.07 \\
(0.17)\end{array}$ & $\begin{array}{l}0.01^{* * * *} \\
(0.01)\end{array}$ & $\begin{array}{l}0.07^{*} \\
(0.01)\end{array}$ & $\begin{array}{l}0.04^{* *} \\
(0.02)\end{array}$ & $\begin{array}{l}0.05^{* *} \\
(0.02)\end{array}$ \\
\hline Bureaucratic Qual. & $\begin{array}{l}2.50 \\
(7.10)\end{array}$ & $\begin{array}{l}5.90 \\
(11.12)\end{array}$ & $\begin{array}{l}3.13 \\
(7.11)\end{array}$ & $\begin{array}{l}2.90 \\
(5.44)\end{array}$ & $\begin{array}{l}3.10 \\
(3.90)\end{array}$ & $\begin{array}{l}1.29 \\
(5.79)\end{array}$ & $\begin{array}{l}0.56 \\
(0.96)\end{array}$ & $\begin{array}{l}2.71 \\
(5.19)\end{array}$ \\
\hline Corruption Control & $\begin{array}{l}-0.70 \\
(0.55)\end{array}$ & $\begin{array}{c}-1.19^{* *} \\
(0.50)\end{array}$ & $\begin{array}{l}-1.11^{* * *} \\
(0.56)\end{array}$ & $\begin{array}{l}1.05 \\
(0.60)\end{array}$ & $\begin{array}{l}0.75 \\
0.90\end{array}$ & $\begin{array}{l}0.82 \\
(0.77)\end{array}$ & $\begin{array}{l}0.43 \\
(0.76)\end{array}$ & $\begin{array}{l}0.17 \\
(0.29)\end{array}$ \\
\hline Democratic Acc. & $\begin{array}{l}-1.12 \\
(1.90)\end{array}$ & $\begin{array}{l}-1.20 \\
(2.21)\end{array}$ & $\begin{array}{l}-0.75 \\
(1.85)\end{array}$ & $\begin{array}{l}-0.99 \\
(1.92)\end{array}$ & $\begin{array}{l}0.48 \\
(0.49)\end{array}$ & $\begin{array}{l}0.51 \\
(0.55)\end{array}$ & $\begin{array}{l}0.50 \\
(0.43)\end{array}$ & $\begin{array}{l}0.67 \\
(0.60)\end{array}$ \\
\hline Political Stability & $\begin{array}{l}-0.75 \\
(0.70)\end{array}$ & $\begin{array}{l}-0.80 \\
(0.67)\end{array}$ & $\begin{array}{l}-0.50 \\
(0.75)\end{array}$ & $\begin{array}{l}-0.61 \\
(0.54)\end{array}$ & $\begin{array}{l}-0.70^{* *} \\
(0.33)\end{array}$ & $\begin{array}{l}-0.41^{* *} \\
(0.19)\end{array}$ & $\begin{array}{l}-0.35^{* * *} \\
(0.17)\end{array}$ & $\begin{array}{c}-0.61^{*} \\
(0.19)\end{array}$ \\
\hline Inflation & $\begin{array}{l}0.01 \\
(0.02)\end{array}$ & $\begin{array}{l}0.04 \\
(0.08)\end{array}$ & $\begin{array}{l}0.03 \\
(0.04)\end{array}$ & $\begin{array}{l}0.06 \\
(0.11)\end{array}$ & $\begin{array}{l}0.05^{*} \\
(0.01)\end{array}$ & $\begin{array}{l}0.06^{* *} \\
(0.03)\end{array}$ & $\begin{array}{l}0.09^{* *} \\
(0.04)\end{array}$ & $\begin{array}{l}0.07^{* * *} \\
(0.04)\end{array}$ \\
\hline Growth & $\begin{array}{l}0.03 \\
(0.07)\end{array}$ & $\begin{array}{l}-0.08 \\
(0.06)\end{array}$ & $\begin{array}{l}0.02 \\
(0.05)\end{array}$ & $\begin{array}{l}0.01 \\
(0.01)\end{array}$ & $\begin{array}{l}-0.02^{* *} \\
(0.01)\end{array}$ & $\begin{array}{l}-0.03 \\
(0.03)\end{array}$ & $\begin{array}{c}-0.02^{* *} \\
(0.01)\end{array}$ & $\begin{array}{l}-0.02^{* * *} \\
(0.01)\end{array}$ \\
\hline$R$-squared & 0.17 & 0.29 & 0.16 & 0.20 & 0.18 & 0.21 & 0.20 & 0.20 \\
\hline Observations & 190 & 206 & 190 & 206 & 270 & 715 & 270 & 715 \\
\hline F-Test & 5.49 & 6.27 & 6.35 & 6.39 & 18.67 & 21.76 & 19.49 & 19.10 \\
\hline Hansen Test & & & 0.17 & 0.19 & & & 0.23 & 0.20 \\
\hline
\end{tabular}

Robust standard errors are reported in parentheses. ****,*** denote 1, 5 and $10 \%$ confidence levels, respectively. In all regressions a constant is also included but not reported.

Schneider, Buehn and Montenegro $(2010)^{18}$, we use a different dataset for informal sector size. In this case, we obtain the informal sector series from Elgin and Oztunali (2012) in which the authors use a two-sector dynamic general equilibrium model to back out the informal sector size for various countries. ${ }^{19}$ Results of regression using this measure for informal sector size are reported in Table 8.

In the final robustness check, we divide our dataset into 4 different regions. These

\footnotetext{
${ }^{18}$ For example Breusch (2005) claims that the technical approach that these authors use is unfit for the purpose of estimating the informal sector size.

${ }^{19}$ See the cited paper for more details and explanations.
} 
Table 8: Robustness Checks: Different IS Data

\begin{tabular}{|c|c|c|c|c|c|c|c|c|}
\hline Dep. Var. & $\begin{array}{l}\text { Debt } \\
\text { (OLS) }\end{array}$ & $\begin{array}{l}\text { Debt } \\
\text { (IV) }\end{array}$ & $\begin{array}{l}\text { FSI } \\
\text { (OLS) }\end{array}$ & $\begin{array}{l}\text { FSI } \\
\text { (IV) }\end{array}$ & $\begin{array}{l}\text { Int. } \\
\text { (OLS) }\end{array}$ & $\begin{array}{l}\text { Int. } \\
\text { (IV) }\end{array}$ & $\begin{array}{l}\text { Default } \\
\text { (OLS) }\end{array}$ & $\begin{array}{l}\text { Default } \\
\text { (IV) }\end{array}$ \\
\hline IS & $4.20^{*}$ & $4.43^{*}$ & $0.84^{*}$ & $1.00^{*}$ & $1.49^{*}$ & $1.18^{*}$ & $0.22^{*}$ & $0.32^{*}$ \\
\hline GDP per-capita & $\begin{array}{l}(0.56) \\
-.1 .72^{* *} \\
(0.69)\end{array}$ & $\begin{array}{l}(0.55) \\
-1.10^{*} \\
(0.53)\end{array}$ & $\begin{array}{l}(0.10) \\
0.15 \\
(0.10)\end{array}$ & $\begin{array}{l}(0.14) \\
0.01 \\
(0.01)\end{array}$ & $\begin{array}{l}(0.14) \\
-0.19 \\
(0.25)\end{array}$ & $\begin{array}{l}(0.18) \\
-0.23 \\
(0.12)\end{array}$ & $\begin{array}{c}(0.03) \\
-0.50^{*} \\
(0.08)\end{array}$ & $\begin{array}{c}(0.10) \\
-0.44^{*} \\
(0.06)\end{array}$ \\
\hline Openness & $\begin{array}{l}0.05 \\
(0.09)\end{array}$ & $\begin{array}{l}0.05 \\
(0.07)\end{array}$ & $\begin{array}{l}0.001 \\
(0.01)\end{array}$ & $\begin{array}{l}0.01 \\
(0.01)\end{array}$ & $\begin{array}{l}0.08^{*} \\
(0.02)\end{array}$ & $\begin{array}{l}0.07 \\
(0.07)\end{array}$ & $\begin{array}{l}0.01 \\
(0.01)\end{array}$ & $\begin{array}{l}0.02 \\
(0.02)\end{array}$ \\
\hline Current Account & $\begin{array}{l}0.06 \\
(0.08)\end{array}$ & $\begin{array}{l}0.08 \\
(0.12)\end{array}$ & $\begin{array}{l}-0.02 \\
(0.02)\end{array}$ & $\begin{array}{l}-0.02 \\
(0.02)\end{array}$ & $\begin{array}{l}0.03^{* *} \\
(0.01)\end{array}$ & $\begin{array}{l}0.04^{* *} \\
(0.02)\end{array}$ & $\begin{array}{l}0.04^{*} \\
(0.01)\end{array}$ & $\begin{array}{l}0.06^{*} \\
(0.02)\end{array}$ \\
\hline Bureaucratic Qual. & $\begin{array}{l}4.60 \\
(8.19)\end{array}$ & $\begin{array}{l}3.87 \\
(7.12)\end{array}$ & $\begin{array}{l}0.50 \\
(0.53)\end{array}$ & $\begin{array}{l}0.52 \\
(0.54)\end{array}$ & $\begin{array}{l}1.50 \\
(1.10)\end{array}$ & $\begin{array}{l}2.07 \\
(1.90)\end{array}$ & $\begin{array}{l}-4.56^{*} \\
(0.96)\end{array}$ & $\begin{array}{l}-4.15^{*} \\
(0.90)\end{array}$ \\
\hline Corruption Control & $\begin{array}{l}-1.76^{* * *} \\
(1.07)\end{array}$ & $\begin{array}{l}-1.19^{* *} \\
(0.51)\end{array}$ & $\begin{array}{l}0.52^{*} \\
(0.16)\end{array}$ & $\begin{array}{l}0.41^{* *} \\
(0.21)\end{array}$ & $\begin{array}{l}0.51 \\
(0.27)\end{array}$ & $\begin{array}{l}0.18 \\
(0.29)\end{array}$ & $\begin{array}{l}2.43^{*} \\
(0.67)\end{array}$ & $\begin{array}{l}1.72 \\
(0.90)\end{array}$ \\
\hline Democratic Acc. & $\begin{array}{l}-1.90 \\
(2.65)\end{array}$ & $\begin{array}{l}-0.80 \\
(1.90)\end{array}$ & $\begin{array}{l}0.25 \\
(0.15)\end{array}$ & $\begin{array}{l}0.19 \\
(0.29)\end{array}$ & $\begin{array}{l}0.52 \\
(0.45)\end{array}$ & $\begin{array}{l}0.71 \\
(0.50)\end{array}$ & & \\
\hline Political Stability & $\begin{array}{l}-0.77 \\
(0.70)\end{array}$ & $\begin{array}{l}-0.54 \\
(0.67)\end{array}$ & $\begin{array}{c}-0.15^{* *} \\
(0.08)\end{array}$ & $\begin{array}{c}-0.10^{* *} \\
(0.05)\end{array}$ & $\begin{array}{c}-0.39^{* *} \\
(0.19)\end{array}$ & $\begin{array}{l}-0.82^{*} \\
(0.20)\end{array}$ & & \\
\hline Inflation & $\begin{array}{l}0.01 \\
(0.06)\end{array}$ & $\begin{array}{l}0.02 \\
(0.07)\end{array}$ & $\begin{array}{l}0.01^{* *} \\
(0.006)\end{array}$ & $\begin{array}{l}0.01^{* * * *} \\
(0.006)\end{array}$ & $\begin{array}{l}0.05^{*} \\
(0.02)\end{array}$ & $\begin{array}{l}0.06^{*} \\
(0.02)\end{array}$ & $\begin{array}{l}0.86^{*} \\
(0.14)\end{array}$ & $\begin{array}{l}0.71^{* *} \\
(0.35)\end{array}$ \\
\hline Growth & $\begin{array}{l}0.02 \\
(0.19) \\
\end{array}$ & $\begin{array}{l}0.10 \\
(0.16) \\
\end{array}$ & $\begin{array}{c}-0.02^{* *} \\
(0.01) \\
\end{array}$ & $\begin{array}{c}-0.02^{* *} \\
(0.01) \\
\end{array}$ & $\begin{array}{c}-0.02^{* *} \\
(0.01) \\
\end{array}$ & $\begin{array}{c}-0.03^{* *} \\
(0.01) \\
\end{array}$ & $\begin{array}{l}0.27 \\
(0.35) \\
\end{array}$ & $\begin{array}{l}0.27 \\
(0.35) \\
\end{array}$ \\
\hline$R$-squared & 0.21 & 0.22 & 0.45 & 0.39 & 0.17 & 0.23 & 0.49 & 0.49 \\
\hline Observations & 396 & 396 & 305 & 305 & 985 & 985 & 65 & 65 \\
\hline F-Test & 6.38 & 6.97 & 22.32 & 19.39 & 18.99 & 20.67 & 109.49 & 102.03 \\
\hline Hansen Test & & 0.21 & & 0.29 & & 0.18 & & 0.15 \\
\hline
\end{tabular}

Robust standard errors are reported in parentheses. *,**,*** denote 1, 5 and $10 \%$ confidence levels, respectively. In all regressions a constant is also included but not reported.

are, OECD and European Union economies (denoted by OECD-EU), Asian and Australian countries (denoted by Asian), Latin American and Caribbean economies (denoted by Latin) and other countries in our 152-country dataset. ${ }^{20}$

\subsection{Summarizing the Empirical Results}

In the previous subsections of this section, we showed that a larger shadow economy size is associated with a higher amount for public debt, higher interest rate spread paid, a

\footnotetext{
${ }^{20}$ In this case for space constraints we only report IV estimates for each case; however OLS results are qualitatively similar to IV regressions.
} 
Table 9: Robustness Checks: Regional Stratification

\begin{tabular}{lllllllll}
\hline \hline Dep. Var. & Debt & Debt & Debt & Debt & Int. & Int. & Int. & Int. \\
\hline \hline & OECD-EU & Asian & Latin & Others & OECD-EU & Asian & Latin & Others \\
\hline \hline IS & $2.36^{*}$ & $3.33^{*}$ & $3.99^{*}$ & $3.28^{*}$ & $1.01^{*}$ & $0.78^{* *}$ & $1.12^{* *}$ & $1.27^{*}$ \\
& $(0.54)$ & $(0.75)$ & $(0.65)$ & $(0.58)$ & $(0.13)$ & $(0.35)$ & $(0.40)$ & $(0.13)$ \\
GDP per-cap. & $-1.20^{* *}$ & $-0.50^{* *}$ & $-0.93^{*}$ & $-1.62^{*}$ & $-0.49^{*}$ & $-0.36^{* * *}$ & -0.56 & $-0.74^{* * *}$ \\
& $(0.56)$ & $(0.20)$ & $(0.25)$ & $(0.26)$ & $(0.18)$ & $(0.20)$ & $(0.48)$ & $(0.39)$ \\
Openness & 0.02 & 0.01 & $-0.03^{* * *}$ & 0.01 & 0.03 & $0.02^{* * *}$ & 0.01 & 0.02 \\
& $(0.03)$ & $(0.01)$ & $(0.02)$ & $(0.01)$ & $(0.02)$ & $(0.02)$ & $(0.01)$ & $(0.02)$ \\
Current Acc. & 0.06 & 0.08 & -0.01 & 0.07 & $0.05^{* *}$ & $0.07^{*}$ & $0.07^{*}$ & $0.05^{* *}$ \\
& $(0.06)$ & $(0.05)$ & $(0.05)$ & $(0.01)$ & $(0.02)$ & $(0.01)$ & $(0.01)$ & $(0.02)$ \\
Bur. Qual. & 3.18 & -0.15 & -2.11 & 1.90 & 0.58 & 0.19 & 0.56 & 1.17 \\
& $(6.90)$ & $(1.12)$ & $(1.85)$ & $(2.12)$ & $(0.90)$ & $(0.17)$ & $(1.65)$ & $(1.90)$ \\
Cor. Cont. & -1.10 & $-1.25^{* * *}$ & $-1.18^{* *}$ & 0.49 & & 0.19 & 0.23 & 0.04 \\
& $(0.61)$ & $(0.63)$ & $(0.51)$ & $(0.71)$ & $(0.69)$ & $(0.36)$ & $(0.27)$ & $(0.09)$ \\
Dem. Acc. & -1.07 & -1.12 & -0.68 & -0.80 & 0.38 & 0.25 & 0.79 & 0.50 \\
& $(1.90)$ & $(1.23)$ & $(0.98)$ & $(0.91)$ & $(0.41)$ & $(0.34)$ & $(0.73)$ & $(0.60)$ \\
Pol. Stab. & -0.57 & -0.78 & -0.74 & -0.16 & -0.30 & $-0.42^{* *}$ & $-0.39^{* *}$ & $-0.41^{* *}$ \\
& $(0.73)$ & $(0.55)$ & $(0.50)$ & $(0.70)$ & $(0.18)$ & $(0.20)$ & $(0.17)$ & $(0.19)$ \\
Inflation & 0.02 & 0.03 & -0.02 & 0.02 & $0.08^{* *}$ & 0.01 & $0.09^{* *}$ & $0.08^{* *}$ \\
& $(0.07)$ & $(0.10)$ & $(0.04)$ & $(0.10)$ & $(0.04)$ & $(0.01)$ & $(0.04)$ & $(0.04)$ \\
Growth & 0.03 & $-0.11^{* * *}$ & -0.02 & 0.01 & -0.03 & $-0.04^{* *}$ & $-0.03^{* *}$ & $-0.05^{* *}$ \\
& $(0.03)$ & $(0.06)$ & $(0.02)$ & $(0.01)$ & $(0.02)$ & $(0.02)$ & $(0.01)$ & $(0.0 .02)$ \\
\hline \hline$R$-squared & 0.12 & 0.15 & 0.16 & 0.17 & 0.21 & 0.41 & 0.45 & 0.48 \\
Observations & 125 & 75 & 76 & 120 & 240 & 158 & 159 & 428 \\
F-Test & 5.10 & 6.10 & 6.21 & 6.39 & 21.17 & 21.17 & 107.49 & 100.10 \\
Hansen Test & 0.14 & 0.16 & 0.13 & 0.19 & 0.21 & 0.17 & 0.16 & 0.18 \\
\hline
\end{tabular}

Robust standard errors are reported in parentheses. *,**,*** denote 1,5 and $10 \%$ confidence levels, respectively. In all regressions a constant is also included but not reported.

higher level of financial instability as measured by the financial stability index and a higher probability of default. One immediate question here might be how important the quantitative influence of the size of the informal economy is. Specifically, we want to understand what the quantitative effect of a variation in the size of the shadow economy is. To this end, in Table 10, we report the \% change of public debt, FSI, interest rate spread, and the default probability (relative to their respective means) when we create a $1 \%$ variation in the informal sector size. ${ }^{21}$

\footnotetext{
${ }^{21}$ We constructed the table using IV estimates of regressions where we used all the independent variables on the right hand side of the regressions.
} 
Table 10: Quantifying Informal Sector's Effects

\begin{tabular}{lllll}
\hline \hline Variable & Public Debt & FSI & Int. Rate & Default Prob. \\
\hline \hline Whole Data & 0.06 & 1.27 & 0.14 & 0.04 \\
DC & 0.07 & & 0.25 & \\
EM & 0.07 & & 0.13 & \\
OECD-EU & 0.07 & & 0.25 & \\
Asian & 0.10 & & 0.09 & \\
Latin & 0.07 & & 0.09 & \\
Others & 0.06 & & 0.09 & \\
\hline \hline
\end{tabular}

Accordingly, for example a $1 \%$ increase in the informal sector size (e.g. from $25 \%$ of GDP to $26 \%$, then the ratio of public debt to GDP increases about $6 \%$ relative to its mean in the whole dataset. The effect of a $1 \%$ increase in the informal sector size also leads to a $127 \%$ increase in the FSI, $14 \%$ increase in the interest rate spread and finally a $4 \%$ increase in the probability of default relative to their respective means. Surely, these effects are different in different subsamples of the data. Therefore, we calculate these numbers for the subset of developed countries (DC), emerging markets (EM), OECD-EU, Asian and Australian, Latin American and other countries separately. ${ }^{22}$ Nevertheless, Table 10 shows that informal sector size not only produces statistically significant coefficients but also has economically significant effects on default risk measures.

\section{$5 \quad$ Policy Implications}

In this section we examine some policy implications of our empirical results presented in the previous section. As documented in the introduction and in the second section of the paper where we have reviewed a theoretical framework, a larger size of the shadow economy is expected to be associated with a higher default risk and high levels of public indebtedness. As we have shown in the previous section, our hypotheses are supported by panel and cross-country regressions for various different measures of sovereign default risk.

In this section we ask whether there are any policy recommendations that one can pre-

\footnotetext{
${ }^{22}$ We can only make this subsample calculation for public debt and interest rate spread due to the availability of data.
} 
scribe to policymakers which would reduce the size of the shadow economy thereby reducing the sovereign default risk. In order to serve for our purpose we estimate the following system $^{23}$ using panel data where we also include factors affecting the size of the informal sector

$$
\begin{array}{r}
\operatorname{Risk}_{i, t}=\beta_{0}+\beta_{1} I S_{i, t}+\sum_{k=2}^{n} \beta_{k} X_{k_{i, t}}+u_{i, t}, \\
\operatorname{Debt}_{i, t}=\beta_{0}+\beta_{1} I S_{i, t}+\sum_{k=2}^{n} \beta_{k} X_{k_{i, t}}+u_{i, t}, \\
I S_{i, t}=\alpha_{0}+\sum_{k=1}^{n} \alpha_{k} Z_{k_{i, t}}+v_{i, t} .
\end{array}
$$

In the above specified system we will specifically look at the estimated values of $\alpha_{k}$ which aim to measure effects of $Z_{k_{i, t}}$ on the size of the shadow economy. Here we include two variables in $Z_{k_{i, t}}$. One of them is the degree of law enforcement which we expect to mitigate the size of the shadow economy as a higher value for the law and order index will improve law enforcement. Another policy tool to create a variation in informal sector size is the level of tax burden, one of the main motives for firms and households to go informal is avoiding income taxes. Therefore, another variable we use as a determinant for informality is the income tax burden defined as the ratio of the revenue from income taxes to GDP. Finally, taking the fact that the informal sector size generally countercyclical (See Roca, Moreno and Sanchez, 2001 and Elgin, 2012 for this.) we also use unemployment rate as a potential determinant for relative informal sector size. We obtain the law and order index from PRS's ICRG similar to the institutional variables used in previous regressions. Tax and unemployment data come from WDI.

The reported results are constructed using the three-stage least square estimator; however similar to the regression analysis in the previous subsections we have also estimated the systems using the GMM estimator (with several different instruments including lagged independent variables) and in these robustness checks did not find any crucial difference with

\footnotetext{
${ }^{23}$ The system is defined assuming the availability of the panel data. In the case of cross-country regressions one should drop the subscript $t$ from the system.
} 
our system estimations. ${ }^{24}$

Table 11: Panel Systems Estimations

\begin{tabular}{|c|c|c|c|c|c|c|c|c|}
\hline Dependent Variable & Debt & IS & FSI & IS & Int.Rate & IS & Default & IS \\
\hline IS & $\begin{array}{l}0.44^{* *} \\
(0.22)\end{array}$ & & $\begin{array}{l}0.04^{*} \\
(0.01)\end{array}$ & & $\begin{array}{l}0.20^{*} \\
(0.03)\end{array}$ & & $\begin{array}{l}0.27^{*} \\
(0.06)\end{array}$ & \\
\hline GDP per-capita & $\begin{array}{l}-0.40^{* *} \\
(0.20)\end{array}$ & & $\begin{array}{l}-0.37^{*} \\
(0.15)\end{array}$ & & $\begin{array}{l}-0.13^{*} \\
(0.05)\end{array}$ & & $\begin{array}{l}-0.38^{*} \\
(0.09)\end{array}$ & \\
\hline Openness & $\begin{array}{l}-0.02 \\
(0.03)\end{array}$ & & $\begin{array}{l}-0.005 \\
(0.003)\end{array}$ & & $\begin{array}{l}-0.005 \\
(0.006)\end{array}$ & & $\begin{array}{l}0.04^{*} \\
(0.01)\end{array}$ & \\
\hline Current Account & $\begin{array}{c}-0.15^{*} \\
(0.03)\end{array}$ & & $\begin{array}{l}-0.002 \\
(0.003)\end{array}$ & & $\begin{array}{l}-0.002 \\
(0.005)\end{array}$ & & $\begin{array}{l}0.08^{*} \\
(0.01)\end{array}$ & \\
\hline Bureaucratic Quality & $\begin{array}{l}9.30^{*} \\
\left(3.31^{*}\right)\end{array}$ & & $\begin{array}{l}0.93^{*} \\
(0.25)\end{array}$ & & $\begin{array}{l}-0.05 \\
(0.47)\end{array}$ & & $\begin{array}{l}-6.58^{*} \\
(1.07)\end{array}$ & \\
\hline Corruption Conrol & $\begin{array}{l}1.31 \\
(1.67)\end{array}$ & & $\begin{array}{l}0.32^{*} \\
(0.11)\end{array}$ & & $\begin{array}{l}0.45 \\
(0.33)\end{array}$ & & $\begin{array}{l}0.72 \\
(0.87)\end{array}$ & \\
\hline Political Stability & $\begin{array}{l}-0.82 \\
(1.22)\end{array}$ & & $\begin{array}{l}0.18^{* *} \\
(0.17)\end{array}$ & & $\begin{array}{l}0.28 \\
(0.22)\end{array}$ & & & \\
\hline Inflation & $\begin{array}{l}-0.18 \\
(0.16)\end{array}$ & & $\begin{array}{l}-0.03^{* *} \\
(0.01)\end{array}$ & & $\begin{array}{l}-0.03 \\
(0.02)\end{array}$ & & $\begin{array}{l}0.74^{*} \\
(0.16)\end{array}$ & \\
\hline Law and Order & & $\begin{array}{l}-6.74^{*} \\
(0.34)\end{array}$ & & $\begin{array}{c}-5.15^{*} \\
(0.39)\end{array}$ & & $\begin{array}{c}-5.41^{*} \\
(0.26)\end{array}$ & & $\begin{array}{c}-7.23^{*} \\
(0.31)\end{array}$ \\
\hline Income Tax & & $\begin{array}{l}1.06^{*} \\
(0.34)\end{array}$ & & $\begin{array}{l}1.17^{*} \\
(0.44)\end{array}$ & & $\begin{array}{l}0.70^{* *} \\
(0.32)\end{array}$ & & $\begin{array}{l}1.05^{*} \\
(0.35)\end{array}$ \\
\hline Unemployment & & $\begin{array}{l}0.27^{* *} \\
(0.14)\end{array}$ & & $\begin{array}{l}0.28^{* *} \\
(0.14)\end{array}$ & & $\begin{array}{l}0.30 * * \\
(0.15)\end{array}$ & & $\begin{array}{l}0.29 * * \\
(0.15)\end{array}$ \\
\hline$\overline{R \text {-squared }}$ & 0.16 & 0.52 & 0.24 & 0.54 & 0.13 & 0.56 & 0.47 & $\overline{0.49}$ \\
\hline Observations & 396 & 396 & 305 & 305 & 985 & 985 & 65 & 65 \\
\hline
\end{tabular}

Heteroskedasticity-consistent $t$-statistics are in parentheses. ${ }^{*},{ }^{* *}, * * *$ denote 1,5 , and $10 \%$ confidence levels, respectively. In all regressions, a constant is also included but not reported.

Results of the systems regressions are reported in Table 11. We have 4 different systems in Table 11, in each a different dependent variable is used as a proxy for Risk. As we can observe from Table 11 higher levels of law and order and capital-output ratio are both associated with a smaller size of the shadow economy which, since the estimate of $\beta_{1}$ is significant and is estimated as negative, in turn reduces the default risk. ${ }^{25}$

According to these results, we can conclude that improving enforcement through en-

\footnotetext{
${ }^{24}$ These robustness check results are also available upon request from the corresponding author.

${ }^{25}$ Even though the sign of the estimated coefficient of $\beta_{1}$ is the main focus here, we also observe that the value of estimated coefficients in system estimations significantly differ from their counterparts in single equation estimates in the previous subsection. Considering that due to the multiple-equation nature of the system we use a different estimator here, this result is not unexpected.
} 
hancing law and order and implementing policies for lower taxes and unemployment have significant effects on sovereign default risk through the informal sector channel. ${ }^{26}$

Using the results in Table 11, we conduct another exercise in Table 12 to quantify the effects of a marginal change in the factors creating variation in informal sector size on default risk measures through their effects on the informal sector size. Specifically, we calculate how a 1 unit increase in the law and order index, and a $1 \%$ reduction in the income tax and unemployment rate change informal sector size and then the debt to GDP ratio, FSI, interest rate and probability of default, respectively. According to Table 12, we can observe that, for example a 1 unit increase in the law and order index (i.e. better law enforcement) have the potential to reduce the public debt (as \% of GDP) by about $3 \%$, FSI by -0.21 the interest rate spread by $-1.08 \%$ and the probability of default by about $2 \%$. Noticing that the standard deviations of these three policy tools, i.e. law and order, income taxes and unemployment, are 1.35, 7.07 and 5.85 respectively; the greatest effect of a one standard deviation improvement in these variables will be by the law and order index followed by a reduction in income tax and unemployment.

Table 12: Effect of Various Policy Tools on Default Risk Measures

\begin{tabular}{lllllllll}
\hline \hline Variable & IS & Debt & IS & FSI & IS & Int. Rate & IS & Default \\
\hline \hline Law and Order & -6.74 & -2.97 & -5.15 & -0.21 & -5.41 & -1.08 & -7.23 & -1.96 \\
Income Tax & -1.06 & -0.47 & -1.17 & -0.04 & -0.70 & -0.14 & -1.05 & -0.28 \\
Unemployment & -0.27 & -0.12 & -0.28 & -0.01 & -0.30 & -0.06 & -0.29 & -0.08 \\
\hline \hline
\end{tabular}

\section{Concluding Remarks}

In this paper we studied the relationship between sovereign default risk and the size of the shadow economy. Building upon a theoretical background and using panel and crosssectional datasets, we have empirically documented that there is a strong causal relation

\footnotetext{
${ }^{26}$ Notice that, compared to the single-equation estimates in the previous subsection some variables lose significance in systems estimations. However, the coefficient of informal sector size is robustly negative in systems estimations.
} 
between the informal sector size and measures of sovereign default risk and country's public indebtedness.

The policy implications that derive complement conclusions from the informal sector literature. Specifically, according to our policy analysis, the public policy should focus more on taking measures to reduce the size of the shadow economy. Increasing tax and law enforcement, enhancing institutional development and lowering income taxes and policies towards lower unemployment can be listed among the measures that one can recommend to policy-makers in societies with a large informal sector size. Our empirical analysis underlines these prescriptions for policy-makers.

Moreover, different from previous studies in the literature, our analysis derives conclusions concerning the costs of informality on international borrowing and emphasizes the attention that needs to be placed on reducing the size of the informal sector production in developing countries as an additional dimension for improving aggregate economic performance. 


\section{References}

1. Aghion, P., Angeletos, G. M., Banerjee, A., Manova, K., 2010. Volatility and growth: Credit constraints and composition of investment. Journal of Monetary Economics, 57 (3), 246-265.

2. Amaral, P.S., Quintin, E., 2006. A competitive model of the informal sector. Journal of Monetary Economics, 53 (7), 1541-1553.

3. Antunes, A., Cavalcanti, T., 2007. Start up costs, limited enforcement, and the hidden economy. European Economic Review, 51 (1), 203-224.

4. Antunes, A., Cavalcanti, T., Villamil, A., 2008. The effect of financial repression and enforcement on entrepreneurship and economic development. Journal of Monetary Economics, 55 (2), 278-297.

5. Balakrishnan, R., Danninger, S., Elekdag, S., Tytell, I., 2009. The transmission of financial stress from advanced to emerging economies, IMF Working Paper No. 09/133.

6. Beck, R., 2001. Do Country Fundamentals Explain Emerging Market Bond Spreads? CFS Working Paper, No. 2001/02.

7. Breusch, T., 2005. Estimating the Underground economy using MIMIC models, Econometrics 0507003, Econ WPA.

8. Calderon, C,. Liu, L., 2003. The direction of causality between financial development and economic growth. Journal of Development Economics, 72 (1), 321-334.

9. Calvo, G. A., 2002. Globalization Hazard and Delayed Reforms in Emerging Markets, Economia 2.

10. Cardarelli, R., Elekdag, S., Lall, S., 2009. Financial stress, downturns, and recoveries, Chapter 4 of the October 2008 WEO report. 
11. Cicek, D., Elgin, C. 2011. Cyclicality of fiscal policy and the shadow economy, Empirical Economics, vol. 41 (3), 725-737.

12. Edwards, S. 1984. LDC Foreign Borrowing and Default Risk: An Empirical Investigation, American Economic Review, 74.

13. Eaton, J., Fernandez, R., 1995. Soverign Debt. Handbook of International Economics, 3 ed. by Gene Grossman and Kenneth Rogoff.

14. Eaton, J., Gersovitz, M., Stiglitz, J. 1986. The Pure Theory of Country Risk. European Economic Review, 30(3).

15. Elgin, C. 2010. Political Turnover, Taxes and the Shadow Economy, Working Papers 2010/08, Bogazici University, Department of Economics.

16. Elgin, C. and Uras, B., 2011. Is Informality a Barrier to Financial Development, Working Paper.

17. Elgin, C. 2012. Cyclicality of the Informal Economy, Working Papers 2012/02, Bogazici University, Department of Economics.

18. Elgin, C. and Oztunali, O., 2012. Shadow Economy around the World: Model Based Estimates, Working Papers 2012/05, Bogazici University, Department of Economics.

19. Faria, A., Mauro, P., Minnoni, M., Zaklan, A. 2006. The External Financing of Emerging Market Countries: Evidence from Two Waves of Financial Globalization, IMF Working Paper.

20. Ferrucci, G., 2003. Empirical Determinants of Emerging Market Economies Sovereign Bond Spreads, Bank of England Working Paper, 205.

21. Fioramanti, M., 2008. Predicting sovereign debt crises using artificial neural networks: A comparative approach, Journal of Financial Stability, 4 (2). 
22. Friedman, E., Johnson, S., Kaufman, D., and Zoldo-Lobaton, P., 2000. Dodging the Grabbing Hand: The Determinants of Unofficial Activity in 69 Countries, Journal of Public Economics 76 (3).

23. Gonzalez-Rozada, M., Levy Yeyati, E. 2008. Global Factors and Emerging Market Spreads, Economic Journal 118.

24. Grandes, M. 2003. Convergence and Divergence in Sovereign Bond Spreads: Theory and Facts from Latin America, Working Paper.

25. Hallerberg, M., Wolff, G., 2008. Fiscal institutions, fiscal policy and sovereign risk premia in EMU, Public Choice.

26. Hart, K., 2008. Informal Economy, The New Palgrave Dictionary of Economics. Second Edition, Eds.Steven N. Durlauf and Lawrence E. Blume. Palgrave Macmillan.

27. Ihrig, J., Moe, K. S., 2004. Lurking in the Shadows: The Informal Sector and Government Policy, Journal of Development Economics. 73 (2), 541-557.

28. Illing, M., Liu, Y., 2006. Measuring financialstress in a developed country: An application to Canada, Journal of Financial Stability, 2 (3), 243-265.

29. Johnson, S., Kaufman, D., Shleifer, A., 1997. The Unofficial Economy in Transition. Brookings Papers on Economic Activity. 28 (2), 159-140.

30. Johnson, S., Kaufman, D., Zoido-Lobaton, P., 1998. Regulatory Discretion and the Unofficial Economy. The American Economic Review 88 (2), 387-392.

31. Loayza, N. V., 1996. The Economics of the Informal Sector: A Simple Model and Some Empirical Evidence from Latin America. Carnegie-Rochester Conference Series on Public Policy 45.

32. Min, H. G., 1998. Determinants of Emerging Market Bond Spreads: Do Economic Fundamentals Matter? World Bank Policy Research Paper 1899. 
33. Panizza, U., Sturzenegger, F., Zettelmeyer, J., 2009. The Economics and Law of Sovereign Debt and Default. Journal of Economic Literature, 47(3).

34. Rauch, J. E., 1991. Modeling the Informal Sector Formally. Journal of Development Economics, 35 .

35. Reinhart, C. M., Rogoff, K. S., Savastano, M. A. 2003. Debt Intolerance, in: W. Brainard and G. Perry (eds.), Brookings Papers on Economic Activity 1.

36. Reinhart, C. M., Rogoff, K. S., 2009. This Time is Different: Eight Century of Financial Folly, Princeton University Press.

37. Roca, J. C. C., Moreno, C. D., and Sanchez, J. E. G., 2001. Underground Economy and Aggregate Fluctuations, Spanish Economic Review, 31, 41-53.

38. Schneider, F., Buehn, A., Montenegro, C. E., 2010. Shadow Economies All over the World: New Estimates for 162 Countries from 1999 to 2007. Policy Research Working Paper 5356, The World Bank.

39. Schneider, F., 2002. The Size and Development of the Shadow Economies of 22 Transition and 21 OECD Countries, IZA Discussion Paper No: 514.

40. Schneider, F., 2005. Shadow Economies Around the World: What Do We Really Know? European Journal of Political Economy, 21(3), 598-642.

41. Schneider, F., Enste, D. H., 2000. Shadow Economies: Size, Causes, and Consequences, Journal of Economic Literature, 38(1), 77-114.

42. Straub, S., 2005. Informal sector: The credit market channel, Journal of Development Economics, 78 (2), 299-321.

43. Torgler, B., Schneider, F., 2007. Shadow Economy, Tax Morale, Governance and Institutional Quality: A Panel Analysis, IZA Discussion Papers, 2563. 
44. Thomas, J. J., 1992. Informal economic activity. University of Michigan Press, Ann Arbor.

45. United Nations Development Programme. 2010. Human Development Report: The Real Wealth of Nations- Pathways to Human Development. New York: UNDP 


\section{Appendix}

\section{Countries:}

OECD-EU: Australia, Austria, Belgium, Canada, Chile, Cyprus, Denmark, Finland, France, Germany, Greece, Iceland, Ireland, Israel, Italy, Japan, Korea (South), Luxemburg,

Malta, Mexico, Netherlands, New Zealand, Norway, Por- tugal, Spain, Sweden, Switzerland, Turkey, UK, USA

Latin American and Caribbean: Argentina, Bahamas, Belize, Bolivia, Brazil, Colombia, Costa Rica, Dominican Republic, Ecuador, El Salvador, Guatemala, Guyana, Haiti, Honduras, Jamaica, Nicaragua, Panama, Paraguay, Peru, Suri- name, Trinidad and Tobago, Uruguay, Venezuela,

Asia - Australia: Bangladesh, Bhutan, Brunei, Cambodia, China, Comoros, Fiji, Hong Kong, India, Indonesia, Laos, Macao, Malaysia, Maldives, Nepal, Pakistan, Papua New Guinea, Philippines, Singapore, Solomon Islands, Sri Lanka, Taiwan, Thailand, Vietnam,

Others: Bosnia and Herzegovina, Bulgaria, Croatia, Czech Republic, Estonia, Georgia, Hungary, Latvia, Lithuania,Mongolia, Poland, Romania, Russia, Slovakia, Slovenia, Tajikistan, Ukraine, Algeria, Bahrain, Egypt, Iran, Jordan, Kuwait, Lebanon, Libya, Morocco, Oman, Qatar, Saudi Arabia, Syria, Tunisia, UAE, Yemen, Angola, Benin,Botswana, Burkina Faso, Burundi, Cameroon, Cape Verde, Central African Republic, Chad, Democratic Republic of Congo, Republic of Congo, Equatorial Guinea, Eritrea, Ethiopia, Gabon, Gambia, Ghana, Guinea, Guinea-Bissau, Ivory Coast, Kenya, Lesotho, Liberia, Madagascar, Malawi, Mali, Mauritania, Mauritius, Mozambique, Namibia, Niger, Nigeria, Rwanda, Senegal, Sierra Leone, South Africa, Sudan, Swaziland, Tanzania, Togo, Uganda, Zambia. 